\title{
Effect of rearing, season of birth, and father on labyrinth behaviour of dairy heifers
}

\author{
Michal Uhrincat $^{(\text {iD }}$ | Jan Broucek ${ }^{a}$ (iD | Anton Hanus | Lucia Macuhova
}

anational Agricultural and Food Centre, Research Institute of Animal Production Nitra, Slovakia.

\begin{abstract}
Objective of this study was to test the hypotheses that heifer's behaviour after 12 months (M) are impacted by rearing (feeding/housing) before weaning, seasons of birth, and father lineage. Fifty-one Holstein heifers (born in year seasons SB1, SB2, SB3, and SB4, originating from 4 fathers) were assigned to one of three rearing treatments: restricted suckling (RS), calf in pen with mother to 21 st day, suck three times daily, then group pen (6 kg milk) to weaning; unrestricted suckling (US), calf in pen with foster cows (6 kg milk) to weaning; conventional rearing (CR), calf in the hutch to 56th day, then group pen to weaning (milk replacer $6 \mathrm{~kg}$ ). After weaning at the 84th day, heifers were kept in groups with the same ration. The labyrinth behaviour was tested in the 12th and 19th $\mathrm{M}$ of the age. In the evaluation factors rearing and season of birth, groups US and SB3 solved the passage of the labyrinth the fastest (868.0 s, $857.4 \mathrm{~s})$, the slowest were CR and SB1 $(1148.2 \mathrm{~s}, 1257.5 \mathrm{~s})$. The results show that the manner (housing/feeding) used to rear heifers and season of birth may impact their later labyrinth behaviour.
\end{abstract}

Keywords: cattle, environment, learning, raising, welfare

\section{Introduction}

In this study, we focused on whether environmental (housing/feeding, birth season) and genetic (father's line) influences can affect dairy heifer behaviour. The calf management in modern dairying differs markedly from those found in nature (von Keyserlingk and Weary 2007; von Keyserlingk et al 2009). Modern housing can cause social disturbances resulting in behavioural problems, which in turn may affect welfare (Bouissou et al 2001; Costa et al 2016; Beaver et al 2019). The early separation of calves from cows after birth is very often used to maximise milk production (Albright and Arave 1997; Margerison et al 1997). The calves are housed in hutches and receive milk replacer (MR) from automatic milk-feeder or via nipple buckets (conventional rearing, also referred as artificially rearing). However, according to more authors, the delayed weaning of calf from mother can improve welfare and behavioural development (Wagenaar and Langhout 2007; Meagher et al 2019; de Oliviera et al 2020).

In past years, many authors reported different manners of keeping dairy cows and calves together (Krohn 2001; Flower and Weary 2003; Loberg et al 2008). The unrestricted methods (also referred as cow-calf contact system) allow all-day contact between foster cows and calves. Each foster cow is suckled by 3-4 calves and not additionally milked (Albright and Arave 1997; Loberg and Lidfors 2001; Köllmann et al 2021). In restricted suckling systems, the mother and her calf are in contact only short parts of the day or a short period after milking (de Passillé et al 2008; Fröberg et al 2008; Roth et al 2009; Johnsen et al 2016).

According to more authors (Rushen and de Passillé 1998; Johnsen et al 2015; Steele 2019; Barth 2020; Kent 2020), much work needs to be done to understand the behavioural mechanisms involved in maternal behaviour and explore the development of fostering techniques that would improve the welfare and learning capabilities of the calf. Social learning through foster cows and other calves may improve learning compared with individually housed calves (de Paula Vieira et al 2012; Costa et al 2015). The calves have more space to movement activities (Rushen et al 2008; Valnickova et al 2015; Johnsen et al 2016).

Also, there is a growing interest in organic calf husbandry. The advantage is whole milk feeding regime to 90 days of age (European Commission 2007; Bilik et al 2013). Dairy heifers should be reared considering their physiological and ethological needs, and only in this way can a good level of animal welfare be guaranteed (Winder et al 2018; Ventura et al 2021).

Dairy cattle need to learn how to interact with their environment to successfully cope with the stressors and respond appropriately to the management changes. The mother-calf bond may have important effects on calves' behaviour development and learning capabilities (Steele 2019; Barth 2020). The speed of the labyrinth solution is used to determine the learning ability of cattle (Kilgour 1981; Kilgour 1987; Albright and Arave 1997; Wechsler and Lea 2007; Broom and Fraser 2007; Horvath and Miller-Cushon 2018). Other authors (Le Neindre 1989; Purcell and Arave 1991; Arave et al 1992a; Veissier 1993; Gailard et al 2014; 
Kälber and Barth 2014; Costa et al 2014; Wagner et al 2015; Valnickova et al 2015; Meagher et al 2015; Costa et al 2016, Johnsen et al 2021; Zhang et al 2021) showed that calves and heifers learning can be influenced by social rearing and housing type.

More authors described cattle behaviour consistency in reactivity of cattle to an ethological test (Hopster et al 1998; Müller and Schrader 2005b; Hedlung and Løvlie 2015; Neave et al 2020). Consistent differences have been found over time (activity in home pen, open-field test, novel object test, and social motivation test) in cattle (Boissy and Bouissou 1995; Schrader 2002; Müller and Schrader 2005a; Gibbons et al 2010; Lecorps et al 2018). The stability times were for 1 month to 6 months (Stehulova et al 2013; Foris et al 2018) in adult cattle (maternal care) and from 107 days to 17 months (arena test and restraint test) (Graunke et al 2013; Reenen van et al 2013) in young cattle.

Dairy cattle respond to high temperatures, their duration and also to changes in humidity and wind speed (Renaudeau et al 2012; Hempel et al 2019). Uncomfortable climatic conditions impair dairy cattle performance, metabolic and health status, behaviour activities and immune response (Rashamol et al 2018; Hempel et al 2019).

More authors (Tao et al 2012; Tao and Dahl 2013; Laporta et al 2017; Herbut et al 2018; Herbut et al 2019; Dahl et al 2020; Roman et al 2021) demonstrated that meteorological conditions may affect the prenatal and postnatal life of dairy cattle. The retarded placental development observed with late-gestation heat stress was directly related to impaired mammary function. Maternal heat stress (hyperthermia) during late gestation also affects the fetus and offspring postnatal life (Tao et al 2011). However, further studies are required to confirm the behavioural responses in the prenatal stressed calves.

The present study aimed to objectively quantify the effects of rearing, the season of birth, and father lineage on the learning ability of dairy heifers.

\section{Materials and Methods}

The experiments comply with the current laws of the Slovakia Republic. The treatment of the animals was approved by the Ministry of Agriculture and Rural Development of the Slovak Republic, no. 115/1995 Z.z. and $377 / 2012$ Z.z. The research was carried out in accordance with the Code of Ethics of the EU Directive 2010/63/EU for animal experiments.

The study was performed in Nitra, Slovakia ( $48^{\circ} 32^{\prime} \mathrm{N}$, $18^{\circ} 03^{\prime} \mathrm{E}$, altitude $144 \mathrm{~m}$ above sea). The oceanic climate is $\mathrm{Cfb}$, according to the Köppen climate classification. (The "C" climate is defined as one with the coldest month's average temperature below $18{ }^{\circ} \mathrm{C}$ and above $-3{ }^{\circ} \mathrm{C}$; the warmest month's average temperature is above $10^{\circ} \mathrm{C}$. The letter " $f$ " represents a climate where no dry season occurs, the "b" the warmest month $<22{ }^{\circ} \mathrm{C}$, but at least four months $>10^{\circ} \mathrm{C}$ ) (Melo et al 2009). According to Lapin et al (2010), geographical coordinates WGS84 are 48.317 (Latitude) and 18.083 (Longitude).
The article is a continuation of the first part of the experiment, which was published in the journal Agriculture (Uhrincat et al 2021). There are also introduced detailed methods.

\subsection{Animals and treatments}

At the birth, 51 Holstein heifers were consecutively assigned into the three rearing treatment groups, balancing birth weight. Three rearing treatments groups were observed (restricted suckling, unrestricted suckling, and conventional rearing). The calves in the group of a restricted suckling of dam (RS, $n=18$ ) were kept separately in an individual pen $(4.5 \times 4.5 \mathrm{~m})$ with mother (milked from 2 nd day at 05:00 and 16:00) to 21st day, suckle a mother's udder 10 minutes 3 times per day $(8: 00,13: 00,18: 00)$. From the $22^{\text {nd }}$ day, the heifers were kept in the loose housing pen $(6 \mathrm{~kg}$ any cow milk per day, $2 \times$ daily $3 \mathrm{~kg}$, bucket with nipple).

The calves in the group of an unrestricted suckling of foster cow (US, $n=16$ ) were 3 days with own mother in individual pen, then pen with non-milked foster cows from 4 th day to weaning. The number of US calves per foster cow was determined according to milk yield of selected cows, so that $6 \mathrm{~kg}$ of milk per calf and day should be available. Group US was housed in a pen of $9 \times 4.5 \mathrm{~m}$ ( 3 nursing cows and 1012 heifer-calves). Cows were tied in the pen, calves loose.

The calves in the group of a conventional rearing (CR, $\mathrm{n}=17$ ) after having nursed their dams in individual pen for 24 $\mathrm{h}$ were kept individually in hutches from 2 nd to 56 th day (bucket with nipple, MR, 2nd day $3 \times 0.5 \mathrm{~kg}, 3 \mathrm{rd}$ day $3 \times 1.0 \mathrm{~kg}$, 4 th day $3 \times 1.5 \mathrm{~kg}$, from 5 th day $6 \mathrm{~kg} /$ day, to 21 st day $3 \times$ daily), then in loose housing pen from 57th day (bucket with nipple, $\mathrm{MR}, 6 \mathrm{~kg} /$ day, $2 \times$ daily) to weaning.

The calves could eat a starter mixture (SM) and alfalfa hay ad libitum until weaning. The RS and US calves could receive SM and alfalfa hay. $\mathrm{CR}$ group calves received SM from bucket and alfalfa hay from crib feeder.

Heifers were also divided according to the season of birth (SB1=January-March, $\mathrm{N}=21 ; \mathrm{SB} 2=$ April-June, $\mathrm{N}=14$; SB3=July-September, $\mathrm{N}=7$; SB4=October-December, $N=9$ ) (Figure 1). The division into rearing groups was as follows: RS (SB1=9, SB2=3, SB3=3, SB4=3, 18); US (SB1=5, SB2=3, SB3=4, $\mathrm{SB} 4=4, \quad 16) ; \quad \mathrm{CR} \quad(\mathrm{SB} 1=7, \quad \mathrm{SB} 2=7, \quad \mathrm{SB} 3=1, \quad \mathrm{SB} 4=2,17)$. Experimental heifers originated from four fathers $(F 1=7$, $F 2=14, F 3=21$, and $F 4=9$ ). The distribution was as follows: RS $(F 1=4, F 2=3, F 3=6, F 4=5,18)$; US (F1=1, F2=7, F3=7, F4=1, 16); $\mathrm{CR}(\mathrm{F} 1=2, \mathrm{~F} 2=4, \mathrm{F3}=8, \mathrm{~F} 4=3,17)$.

All animals were weaned at the age of 84 days. Each treatment group had its pens. On the 360th day, the live body weight (LBW) was the highest in the US group (RS $344.45 \mathrm{~kg}$, US $355.24 \mathrm{~kg}, \mathrm{CR} 332.98 \mathrm{~kg}$ ). On the 570th day, the highest LBW was re-recorded in US group and the lowest one in CR (RS $531.37 \mathrm{~kg}$, US $542.28 \mathrm{~kg}$, CR $519.58 \mathrm{~kg}$ ). The daily health evaluation methods were used (Slavik et al 2009; Novak et al 2010). The breeding program of heifers began at 13 months of age; Al bred the heifers with frozen-thawed semen. Two heifers were culled from the RS group, one at 18 months of age for infections causing a respiratory problem (pneumonia) 
and the other for injury accident (limb fracture) at 19 months of age. One heifer of the CR group had to be culled due to foetal loss (122 days of pregnancy) at 19 months.

\subsection{The labyrinth tests}

The learning ability (Hebb-Williams closed field test) was evaluated in the $12^{\text {th }}$ and 19th month of life. The experimental facility was constructed in an $8 \times 14 \mathrm{~m}$ indoor room with concrete floor (not grooved) and a height of $6.2 \mathrm{~m}$. The starting box $(2.5 \times 3 \mathrm{~m})$ was located in the left corner of the labyrinth and the goal place in the right corner of the opposite side of the labyrinth facility. The room was equipped with a three video cameras with built-in microphones that were mounted under the ceiling, above the starting box, the labyrinth unit segments and the goal place so that the whole area of the labyrinth was visible. The cameras were connected to a video recorder and monitor in a laboratory room. Problem tests (labyrinth unit segments) were constructed from $2 \mathrm{~m}$ high walls. Heifers solved six tests during three consecutive days. Tasks 1 and 2 required a left side solution, tests 3 and 4 a right-side solution, and 5 and 6 a central solution (Kilgour 1981). Each test was performed twice (four runs per day), and heifers were observed in a random order in each test. A detailed scheme is given in the recent work of the authors Broucek et al (2021).

If the heifer stood without movement in the enter part or other parts of the labyrinth apparatus for more than 3 minutes, it was forced gently to movement. The motivation to finish the problem was access to a $0.5 \mathrm{~kg} \mathrm{CM}$ at the exit. The heifer was allowed to eating for only a few seconds. The time of standing in the labyrinth, the speed of traversing the labyrinth and vocalisation were recorded.

The ethological laboratory belonging to the labyrinth facility (separated from the labyrinth by a brick wall) was equipped with video cameras to film the animal activities continuously. Behavioural data were collected by videotapes and processed by electronic software. The heifer behaviour was controlled during tests directly from a monitor screen and analysed from videotapes (Observer XT) afterwards. A total of $47.3 \mathrm{~h}(2837 \mathrm{~min})$ of video recordings were investigated. The time consumption for the analysis of one heifer at the age of 12 and 19 months were $29 \mathrm{~min}$ and 28 $\min$.

\subsection{Statistical calculations}

The data were analysed by the statistical package STATISTIX, Version 10.0. The dependent variables were labyrinth parameters. The independent variables were treatment group $(T)$, the season of birth $(S)$, and father lineage (F). The effects of observed factors (treatment, season of birth, and father lineage) were evaluated by General linear model ANOVA (three-factorial with interactions) with the all effects considered as fixed effect (treatment), random effects (season of birth, and father lineage), and with error term as random effect distributed by model equation. We used the classical distribution $P$ values to express statistical significance, $* P<0.05 ; * * P<0.01$; ${ }^{* * *} P$ $<0.001$. If the $P$-value was in the range of 0.05 to 0.1 , we evaluated it as a tendency.

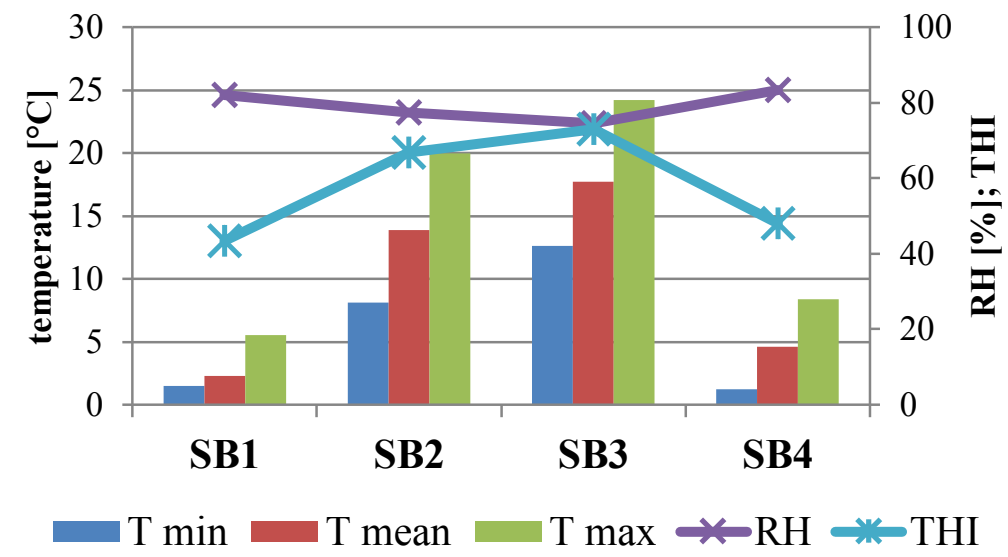

Figure 1 Climatological parameters during seasons of birth. SB1=January-March, SB2=April-June, SB3=July-September, SB4=OctoberDecember, $\mathrm{T}=$ temperature, $\mathrm{RH}=$ relative humidity, $\mathrm{THI}=$ temperature-humidity index.

Differences among groups were tested by Comparisons of Mean Ranks. Bonferroni's test tested significant differences among means. All values are reported as means \pm standard error of the mean (SE). The interactions between observed factors (treatment, season of birth, father lineage) were also computed.

The following model of General AOV/AOCV on observed factors (treatment, season of birth, and father) was used:
$Y i j k=\mu+T i+S j+F k+\alpha i j+\beta i k+\gamma j k+\varepsilon i j k$

where Yijk is a dependent variable, $\mu$ is the overall mean, $T i$ is the effect of factor treatment on the level $i, S j$ is the effect of factor season of the birth on the level j, Fk is the effect of factor father lineage on the level $k$, aij is the interaction between factor $T$ on the level $i$ and factor $S$ on the level $j, \beta i k$ is the interaction between factor $T$ on the level $i$ and factor $F$ 
on the level $k, j j k$ is the interaction between factor $S$ on the level $j$ and factor $F$ on the level $k$, and $\varepsilon i j k$ is the residual error.

The consistency of the behavioural test parameters over time was determined using Spearman's rank correlation coefficients.

\section{Results}

\subsection{Factor rearing (housing/feeding)}

The shortest total standing time in the labyrinth was found in the 12th and 19th month in the heifers of the US group and the longest one in the heifers of the CR group (RS $652.87 \pm 97.76 \mathrm{~s}$, US $419.46 \pm 111.65 \mathrm{~s}, \mathrm{CR} 673.91 \pm 105.75 \mathrm{~s}$, $\mathrm{P}=0.1839$; RS $662.33 \pm 98.17 \mathrm{~s}$, US $389.34 \pm 105.99 \mathrm{~s}, \mathrm{CR}$ $670.26 \pm 100.81 \mathrm{~s}, \mathrm{P}=0.1839)$. At the age of 12 months, significant differences were noted in Test 4 (RS 111.64 \pm 20.76 s, US $35.91 \pm 23.71 \mathrm{~s}, \mathrm{CR} 115.52 \pm 22.46 \mathrm{~s}, \mathrm{P}=0.0273$, US:CR*). In another evaluation of the labyrinth at the age of 19 months, differences were found in the solution of Test 3 (RS $127.22 \pm 19.78$ s, US $46.68 \pm 21.35$ s, CR $121.76 \pm 20.31$ s, $\mathrm{P}=0.0143$, US:RS, $C R^{*}$ ) (Table 1).

Table 1 Times of standing in the labyrinth (s).

\begin{tabular}{|c|c|c|c|c|c|c|c|}
\hline \multirow{2}{*}{ Test } & \multirow[b]{2}{*}{ Group } & \multicolumn{3}{|c|}{12 months } & \multicolumn{3}{|c|}{19 months } \\
\hline & & $\mathrm{N}$ & $x \pm S E$ & $P$-value/ significance & $\mathrm{N}$ & $x \pm S E$ & $P$-value/significance \\
\hline \multirow[t]{3}{*}{1} & RS & 18 & $121.17 \pm 15.16$ & 0.8692 & 16 & $71.31 \pm 14.64$ & 0.6009 \\
\hline & US & 16 & $108.70 \pm 17.36$ & & 16 & $71.86 \pm 15.80$ & \\
\hline & CR & 17 & $114.80 \pm 16.24$ & & 16 & $54.43 \pm 15.03$ & \\
\hline \multirow[t]{3}{*}{2} & RS & 18 & $99.03 \pm 19.11$ & 0.0609 & 16 & $86.12 \pm 17.37$ & 0.1984 \\
\hline & US & 16 & $56.45 \pm 21.90$ & & 16 & $55.24 \pm 18.76$ & \\
\hline & CR & 17 & $125.10 \pm 20.47$ & & 16 & $98.72 \pm 17.84$ & \\
\hline \multirow[t]{3}{*}{3} & RS & 18 & $125.89 \pm 19.65$ & 0.0810 & 16 & $127.22 \pm 19.78$ & $0.0143^{*}$ \\
\hline & US & 16 & $55.77 \pm 22.50$ & & 16 & $46.68 \pm 21.35$ & $2: 1,3^{*}$ \\
\hline & $\mathrm{CR}$ & 17 & $100.03 \pm 21.05$ & & 16 & $121.76 \pm 20.31$ & \\
\hline \multirow[t]{3}{*}{4} & RS & 18 & $111.64 \pm 20.76$ & $0.0273^{*}$ & 16 & $114.35 \pm 21.30$ & 0.144 \\
\hline & US & 16 & $35.91 \pm 23.71$ & $2: 3^{*}$ & 16 & $66.78 \pm 22.99$ & \\
\hline & CR & 17 & $115.52 \pm 22.46$ & & 16 & $124.13 \pm 21.87$ & \\
\hline \multirow[t]{3}{*}{5} & RS & 18 & $95.05 \pm 20.82$ & 0.4323 & 16 & $151.38 \pm 22.91$ & 0.0873 \\
\hline & US & 16 & $74.32 \pm 23.84$ & & 16 & $78.51 \pm 24.73$ & \\
\hline & CR & 17 & $114.11 \pm 22.31$ & & 16 & $139.31 \pm 23.52$ & \\
\hline \multirow[t]{3}{*}{6} & RS & 18 & $101.35 \pm 22.69$ & 0.9198 & 16 & $111.94 \pm 25.51$ & 0.2226 \\
\hline & US & 16 & $89.00 \pm 25.98$ & & 16 & $70.27 \pm 27.54$ & \\
\hline & CR & 17 & $101.5 \pm 24.31$ & & 16 & $131.91 \pm 26.19$ & \\
\hline Total for & RS & 18 & $652.87 \pm 97.76$ & 0.1839 & 16 & $662.33 \pm 98.17$ & 0.0953 \\
\hline \multirow[t]{2}{*}{ all tests } & US & 16 & $419.46 \pm 111.65$ & & 16 & $389.34 \pm 105.99$ & \\
\hline & CR & 17 & $673.91 \pm 105.75$ & & 16 & $670.26 \pm 100.81$ & \\
\hline
\end{tabular}

$\mathrm{N}$ (number of animals); SE (standard error of the mean); ${ }^{*} P<0.05$;

The tendency in the labyrinth crossing time was similar to the labyrinth standing time. The fastest were in both times of the observation (12 and 19 months) heifers of the US group, and the slowest were heifers of the CR group (RS 1148.2 $\pm 112.21 \mathrm{~s}$, US $868.0 \pm 128.48 \mathrm{~s}, \mathrm{CR} 1234.4 \pm 120.20 \mathrm{~s}$, $\mathrm{P}=0.0900$; RS $1153.2 \pm 107.41 \mathrm{~s}$, US $869.4 \pm 115.96 \mathrm{~s}, \mathrm{CR}$ 1219.2 $\pm 110.29 \mathrm{~s}, \mathrm{P}=0.0640$ ).

Also, significant differences were recorded in Test 4 (12 months) and in Test 3 (19 months) (RS 193.16 $\pm 26.81 \mathrm{~s}$, US $100.18 \pm 30.69$ s, CR $194.52 \pm 28.72$ s, $P=0.0423$, US:RS, CR*; RS $207.62 \pm 22.45$ s, US $107.25 \pm 24.24$ s, CR $207.88 \pm 23.06$ s, $\mathrm{P}=0.0045$, US:CR**, RS:US*) (Table 2).

Similar tendencies were demonstrated in both vocalisation behaviour assessment terms, 12 and 19 months. The heifers of the RS group showed the highest number of vocalisations and the heifers of the CR group the least (RS
24.70 \pm 3.31 , US 19.78 \pm 3.78, CR $15.33 \pm 3.58, P=0.1474$; RS $18.43 \pm 2.90$, US $12.73 \pm 3.13$, CR $8.50 \pm 2.97, P=0.0637$ ).

Significant differences between the response of the groups used were found at the age of 19 months, in tests 3 and 5 (RS 4.17 \pm 0.66 , US 1.98 $\pm 0.71, C R ~ 1.94 \pm 0.68, P=0.0467 *$, $\mathrm{RS}: \mathrm{US}, \mathrm{CR}^{*}$; RS 5.11 \pm 0.83 , US $3.12 \pm 0.89, \mathrm{CR} 1.78 \pm 0.85$, $\mathrm{P}=0.0252^{*}, \mathrm{RS}: \mathrm{CR}^{*}$ ) (Table 3).

At the 12th and 19th month, the shortest standing and crossing times in the labyrinth were tended in the heifers of the US group and the longest one in the heifers of the CR group. However, the differences were found in the solution of only some tests.

These results suggest that providing enrichment of environment during the milk-feeding period can change responses. Heifers housed in unenriched environments (CR) or enriched environment for 21 days only (RS) had reduced flexibility in labyrinth tests. 
Table 2 Times of the labyrinth crossing (s).

\begin{tabular}{|c|c|c|c|c|c|c|c|}
\hline \multirow[b]{2}{*}{ Test } & \multirow[b]{2}{*}{ Group } & \multicolumn{3}{|c|}{12 months } & \multicolumn{3}{|c|}{19 months } \\
\hline & & $\mathrm{N}$ & $x \pm S E$ & $P$-value/ significance & $\mathrm{N}$ & $x \pm S E$ & $P$-value/ significance \\
\hline \multirow[t]{3}{*}{1} & RS & 18 & $211.33 \pm 17.41$ & 0.1745 & 16 & $171.22 \pm 20.03$ & 0.6372 \\
\hline & US & 16 & $171.12 \pm 19.94$ & & 16 & $167.02 \pm 21.62$ & \\
\hline & $\mathrm{CR}$ & 17 & $218.04 \pm 18.66$ & & 16 & $147.17 \pm 20.56$ & \\
\hline \multirow[t]{2}{*}{2} & RS & 18 & $162.26 \pm 22.36$ & 0.0782 & 16 & $158.01 \pm 20.66$ & 0.0955 \\
\hline & CR & 17 & $192.71 \pm 23.96$ & & 16 & $195.29 \pm 21.22$ & \\
\hline \multirow[t]{3}{*}{3} & RS & 18 & $206.65 \pm 24.27$ & 0.0948 & 16 & $207.62 \pm 22.45$ & $0.0045^{* *}$ \\
\hline & US & 16 & $132.86 \pm 27.79$ & & 16 & $107.25 \pm 24.24$ & $1: 2^{*}$ \\
\hline & CR & 17 & $204.41 \pm 26.00$ & & 16 & $207.88 \pm 23.06$ & $2: 3^{* *}$ \\
\hline \multirow[t]{3}{*}{4} & RS & 18 & $193.16 \pm 26.81$ & $0.0423^{*}$ & 16 & $192.58 \pm 25.87$ & 0.2387 \\
\hline & US & 16 & $100.18 \pm 30.69$ & $2: 1,3^{*}$ & 16 & $154.62 \pm 27.93$ & \\
\hline & CR & 17 & $194.52 \pm 28.72$ & & 16 & $215.76 \pm 26.57$ & \\
\hline \multirow[t]{3}{*}{5} & RS & 18 & $184.28 \pm 27.37$ & 0.3490 & 16 & $242.00 \pm 24.61$ & 0.0749 \\
\hline & US & 16 & $174.51 \pm 31.33$ & & 16 & $167.76 \pm 26.57$ & \\
\hline & $\mathrm{CR}$ & 17 & $227.47 \pm 29.31$ & & 16 & $240.73 \pm 25.28$ & \\
\hline \multirow[t]{3}{*}{6} & RS & 18 & $190.55 \pm 26.51$ & 0.8228 & 16 & $181.75 \pm 28.61$ & 0.1882 \\
\hline & US & 16 & $173.09 \pm 30.35$ & & 16 & $139.17 \pm 30.88$ & \\
\hline & $\mathrm{CR}$ & 17 & $197.26 \pm 28.40$ & & 16 & $212.35 \pm 29.37$ & \\
\hline Total & RS & 18 & $1148.2 \pm 112.21$ & 0.0900 & 16 & $1153.2 \pm 107.41$ & 0.0640 \\
\hline for all & US & 16 & $868.0 \pm 128.48$ & & 16 & $869.4 \pm 115.96$ & \\
\hline tests & CR & 17 & $1234.4 \pm 120.20$ & & 16 & $1219.2 \pm 110.29$ & \\
\hline
\end{tabular}

$\mathrm{N}$ (number of animals); SE (standard error of the mean); ${ }^{*} P<0.05 ;{ }^{* *} P<0.01$

Table 3 Numbers of vocalisation in the labyrinth (s).

\begin{tabular}{|c|c|c|c|c|c|c|c|}
\hline \multirow[b]{2}{*}{ Test } & \multirow[b]{2}{*}{ Group } & \multicolumn{2}{|c|}{12 months } & \multicolumn{3}{|c|}{19 months } & \multirow[b]{2}{*}{ P-value/ significance } \\
\hline & & $\mathrm{N}$ & $x \pm S E$ & P-value/ significance & $\mathrm{N}$ & $x \pm S E$ & \\
\hline \multirow[t]{3}{*}{1} & $\mathrm{RS}$ & 18 & $7.19 \pm 1.24$ & 0.1127 & 16 & $4.04 \pm 1.09$ & 0.1799 \\
\hline & US & 16 & $5.75 \pm 1.42$ & & 16 & $1.85 \pm 1.17$ & \\
\hline & $\mathrm{CR}$ & 17 & $3.52 \pm 1.33$ & & 16 & $1.17 \pm 1.12$ & \\
\hline \multirow[t]{2}{*}{2} & RS & 18 & $2.81 \pm 0.75$ & 0.6208 & 16 & $1.22 \pm 0.29$ & 0.4766 \\
\hline & $\mathrm{CR}$ & 17 & $2.50 \pm 0.81$ & & 16 & $0.74 \pm 0.30$ & \\
\hline \multirow[t]{3}{*}{3} & RS & 18 & $5.42 \pm 1.03$ & 0.2638 & 16 & $4.17 \pm 0.66$ & $0.0467^{*}$ \\
\hline & US & 16 & $3.42 \pm 1.18$ & & 16 & $1.98 \pm 0.71$ & $1: 2,3^{*}$ \\
\hline & $\mathrm{CR}$ & 17 & $3.16 \pm 1.10$ & & 16 & $1.94 \pm 0.68$ & \\
\hline \multirow[t]{2}{*}{4} & RS & 18 & $3.06 \pm 0.66$ & 0.3217 & 16 & $1.76 \pm 0.51$ & 0.1381 \\
\hline & US & 16 & $1.53 \pm 0.76$ & & 16 & $2.10 \pm 0.55$ & \\
\hline \multirow[t]{3}{*}{5} & RS & 18 & $4.01 \pm 0.79$ & 0.2265 & 16 & $5.11 \pm 0.83$ & $0.0252 *$ \\
\hline & US & 16 & $3.78 \pm 0.90$ & & 16 & $3.12 \pm 0.89$ & $1: 3^{*}$ \\
\hline & $\mathrm{CR}$ & 17 & $2.25 \pm 0.84$ & & 16 & $1.78 \pm 0.85$ & \\
\hline \multirow[t]{3}{*}{6} & $\mathrm{RS}$ & 18 & $2.42 \pm 0.85$ & 0.1600 & 16 & $2.13 \pm 0.66$ & 0.8592 \\
\hline & US & 16 & $3.75 \pm 0.98$ & & 16 & $2.56 \pm 0.71$ & \\
\hline & CR & 17 & $1.30 \pm 0.91$ & & 16 & $2.09 \pm 0.67$ & \\
\hline Total for & $\mathrm{RS}$ & 18 & $24.70 \pm 3.31$ & 0.1474 & 16 & $18.43 \pm 2.90$ & 0.0637 \\
\hline \multirow[t]{2}{*}{ all tests } & US & 16 & $19.78 \pm 3.78$ & & 16 & $12.73 \pm 3.13$ & \\
\hline & CR & 17 & $15.33 \pm 3.58$ & & 16 & $8.50 \pm 2.97$ & \\
\hline
\end{tabular}

$\mathrm{N}$ (number of animals); SE (standard error of the mean); ${ }^{*} P<0.05$; 


\subsection{Factors season of birth and father lineage}

At the age of 12 months, there was a tendency of the shortest and longest total standing time in group SB3 and in group SB1 (SB1 711.7 \pm 96.8 S, SB2 672.5 \pm 112.53 S, SB3 381.34 $\pm 145.5 \quad$ S, $\quad$ SB4 562.8 $\pm 135.6 \quad S$, $P=0.1664)$. Significant differences were calculated in Test 1 and Test 6 $(\mathrm{P}=0.0327, \mathrm{SB} 1: \mathrm{SB} 3 * ; \mathrm{P}=0.0079 * *, \mathrm{SB} 1: \mathrm{SB} 3 * *)$. The trend was maintained until the age of 19 months (SB1 698.2 $\pm 95.9 \mathrm{~s}$, SB2 614.5 \pm 105.9 s, SB3 379.4 \pm 136.1 s, SB4 603.8 \pm 132.2 s, $P=0.2941)$. Significant differences were found in Test 1 (SB1 89.6 $\pm 14.3 \quad$ s, SB2 90.8 \pm 15.8 s, SB3 19.4 \pm 20.3 s, SB4 63.6 \pm 19.7 s, $P=0.0254$, SB3:SB1,2*).

A similar situation was showed in the time of crossing the labyrinth. SB3 heifers needed the least time at the age of 12 months, and SB1 heifers were the slowest (SB1 1257.5 \pm 109.7 , SB2 1176.0 \pm 129.1 , SB3 857.4 \pm 167.5 , SB4 1043.3 $\pm 156.0, P=0.1643)$. Significant differences were recorded in Test 6 (SB1 277.5 \pm 25.7 s, SB2 225.7 \pm 30.5 s, SB3 87.1 \pm 39.6 s, SB4 157.5 $\pm 36.8, \quad P=0.0010, S B 1: S B 3 *$, $\left.\mathrm{SB} 2: \mathrm{SB} 3^{* *}\right)$. Seven months later, it was again the fastest SB3 group and the slowest SB1 group (SB1 1257.3 \pm 104.9, SB2 1141.3 $\pm 115.9, \quad$ SB3 838.5 \pm 148.9 , SB4 1085.1 \pm 144.6 , $\mathrm{P}=0.1508)$. Significant differences were recorded in Test 1 (SB1 192.9 \pm 19.5 s, SB2 192.7 \pm 21.6 s, SB3 96.1 \pm 27.8 s, SB4 165.5 $\left.\pm 26.9, \mathrm{P}=0.0285, \mathrm{SB1}: \mathrm{SB}{ }^{*}\right)$.

In ethological tests at 12 months, the highest vocalisation reaction was observed in group SB1 and the quietest heifers were from group SB4 (SB1 29.8 \pm 3.3 ,

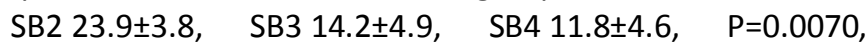
$\left.\mathrm{SB1}: \mathrm{SB} 4 *, \mathrm{SB1}: \mathrm{SB} 3^{* *}\right)$. There was also a significant difference in Test 1 (SB1 9.7 $\pm 1.2, \quad S B 26.7 \pm 1.4, \quad S B 3$ 1.6.1 \pm 1.9 s, SB4 3.9 $\pm 1.7, \mathrm{P}=0.0026, \mathrm{SB} 1: \mathrm{SB} 4 *, \mathrm{SB1}: \mathrm{SB} 3 * *)$ ). At 19 months, there were no significant differences between the vocalisation response according to the season of the birth $(P=0.4653)$.

However, significant significance was recorded in the distribution of heifers by fathers. At the age of 12 months, heifers after $\mathrm{F} 4$ had the most vocalization and animals after F1 the least in all tests (F1 $16.7 \pm 5.5, F 220.3 \pm 4.2, F 318.9 \pm$ 2.9, F4 $\left.23.8 \pm 4.3, \mathrm{P}=0.0491^{*}, \mathrm{~F} 3: \mathrm{F} 4{ }^{*}\right)$. Significant differences were also noted in Tests 4 and 6 (F1 1.2 \pm 1.1 , F2 2.0 $\pm 0.85, F 32.2 \pm 0.6, F 43.4 \pm 0.8, \quad P=0.0224^{*}, F 2: F 3 *$; F1 3.6 $\pm 1.4, F 2 ~ 2.65 \pm 1.1, F 31.6 \pm 0.7$, F4 2.1 $\pm 1.1, P=0.0229$, F3:F4*).

\subsection{Consistency of labyrinth behaviour over time}

Repeatability between the parameters of labyrinth behaviour at the age of 12 months and 19 months was proved by highly significant correlations (Table 4). The times of standing in the labyrinth correlated significantly in all tests. The significant relationships between the times of traversing the labyrinth were found during five tests, the exception was only the third test. The least consistent indicator was the number of vocalisations. The differences in the third, fourth and sixth tests were shown in this case. However, in the evaluation for all six tests, very close relationships were recorded, positive correlations were at the levels of $P<0.001$ $\left(r=0.6660^{* * *}, r=0.7703^{* * *}, r=0.5471^{* * *}\right)$.

\section{Discussion}

\subsection{Factor rearing (housing/feeding)}

Calf-heifers raised in individual hutches with limited movement (CR) cannot sufficiently express their social behaviour; they became more challenging to adapt to the new situation and, therefore, impaired learning abilities. This was pointed by the other authors (Arave et al 1992b; Veissier and Le Neindre 1992; Costa et al 2016). Calves housed individually with maternal deprivation are less able to cope with stress and are more fearful than pair-housed calves (Lauber et al 2006; Latham and Mason 2008; Jensen and Larsen 2014; Horvath et al 2017). Lack of social communication could cause a relevant level of stress in the calves, affecting their later behaviour. Socially reared calves are less fearful (Wagner et al 2013; Zhang et al 2021).

On the other hand, the CR group's prolonging of standing or crossing time could be accounted for as an increased exploratory reaction. It is yet to be ascertained whether we will consider this exploratory behaviour as positive or negative. It can express higher interest in the environment and, thus, a higher intelligence.

The shortest time of running across the labyrinth was recorded in the US group. In foster cow rearing systems (such as US), calves have to compete with other calves, which can affect their behaviour after weaning or calving. Foster cow care and social contact also played an important role. The calf also learns from the other animals in the group (Gaillard et al 2014; Meagher et al 2016; Meagher et al 2019). These results confirm the previous findings (Flower and Weary 2001; Wagner et al 2012; Costa et al 2016). Heifers raised with their mother or foster cows were more socially active than heifers kept individually (RS and US against CR).

Similar tendencies were demonstrated in both vocalisation behaviour assessment terms, 12 and 19 months. The heifers of the RS group showed the highest number of vocalisations, and the heifers of the $C R$ group the least. The rearing treatment groups differed significantly. CR heifers cannot quickly cope with the new situation and, therefore, are most vocalised. When we compare the groups US and CR, it is evident that the mother separation time was very different. The heifers of the CR group could not form a bond with the mother or foster cow during the milk feeding period, but the heifers in the RS group had to be closely dependent on the mother. The vocal response may express the reaction of the heifer to social isolation in the labyrinth. An animal not adapted to stay in an unfamiliar environment is frightened and stressed out when alone (Siebert et al 2011; Burman et al 2008; Green et al 2018; Lecorps et al 2018). Mooing has been used as a measure of distress and fear in farm animals (Romeyer and Bouissou 1992; Manteuffel et al 2004), and vocalisation assessments in behavioural studies are a source of important information about the physiology and welfare state and related to the expression of social behaviours 
(Stehulova et al 2008; Meen et al 2015; Herbut et al 2021; Lecorps et al 2018).

\subsection{Factors season of birth and father lineage}

At 12 months, it tended to have the shortest and longest total standing time in group SB3 and group SB1. The trend was maintained until the age of 19 months. A similar situation was shown in the time of crossing the labyrinth. SB3 heifers needed the least time at the age of 12 months, and SB1 heifers were the slowest. To explain, we have two options, namely, influences of cold stress and prenatal stress. Calves are the most susceptible to cold stress right after they are born. In Slovakia, calves born in the late winter and early spring often experience sustained cold periods during the first weeks of life. For newborns, the lower threshold temperature is about $15^{\circ} \mathrm{C}$. Under this threshold, the calf must to use limited body energy reserves. A negative energy balance could be developed (Anderson and Bates 1984; Buttler et al 2006; Nonnecke et al 2009; Angrecka and Herbut 2015; Roland et al 2016).

The increased energy expenditure to warm the body results in a series of physiological and behavioural responses. This ability to adapt to a lowering of the energy intake is, without doubt, beneficial to the survival of the individual (Gordon 1997; Krachun et al 2010; Miguel-Pacheco et al
2015; Bell et al 2021). According to authors Shetty (1999), and Han and Dingemanse (2015), behaviour is focused mainly on the distribution of time and energy for the necessary activities.

Miguel-Pacheco et al (2015) and Budzynska and Weary (2008) demonstrated that the movement time reflects dairy calves' energy intake. This can explain why the SB1 heifers were the slowest in solving labyrinth tests. During the early neonatal period, adverse climatic conditions disrupt thermal balance and may result in behavioural changes in early and later age (Carstens 1994; Collier et al 2006).

The prenatal stress (stress experienced by the mother with impact on the foetal ontogeny) can cause longer-term behavioural changes in the offspring (Broucek et al 2002; Gräbner et al 2009). Braastad (1998) reported that prenatally stressed animals show a reduced exploratory behaviour and impaired learning ability.

Some authors concluded that heat stress during gestation also influenced the calves and kids' activity patterns and exploratory behaviour in early life (Laporta et al 2017; Coloma-García et al 2020). This may explain the rapid solution of labyrinth tests by a group of heifers born between July and September (SB3). However, studies exploring the effect of uterus heat stress on dairy cattle behaviour, especially labyrinth behaviour, are lacking.

Table 4 Spearman correlations of labyrinth behaviour at 12 and 19 months of age.

\begin{tabular}{lllll}
\hline Test & & Time of standing $(\mathrm{s})$ & Time of crossing $(\mathrm{s})$ & Number of vocalisation \\
\hline 1 & $\mathrm{r}$ & 0.6271 & 0.5112 & 0.1639 \\
& $\mathrm{p}$ & $0.0000^{* * *}$ & $0.0002^{* * *}$ & 0.2698 \\
2 & $\mathrm{r}$ & 0.4613 & 0.4622 & 0.2086 \\
& $\mathrm{p}$ & $0.0012^{* *}$ & $0.0011^{* *}$ & 0.1590 \\
& $\mathrm{r}$ & 0.3262 & 0.1807 & 0.4472 \\
& $\mathrm{p}$ & $0.0256^{*}$ & 0.2179 & $0.0018^{* *}$ \\
& $\mathrm{r}$ & 0.5308 & 0.5060 & 0.3636 \\
5 & $\mathrm{p}$ & $0.0002^{* * *}$ & $0.0003^{* * *}$ & $0.0123^{*}$ \\
& $\mathrm{r}$ & 0.4864 & 0.4982 & 0.2003 \\
6 & $\mathrm{p}$ & $0.0006^{* * *}$ & $0.0004^{* * *}$ & 0.1763 \\
& $\mathrm{r}$ & 0.3389 & 0.4038 & 0.4465 \\
\multirow{2}{*}{ Total for all } & $\mathrm{p}$ & $0.0202^{*}$ & $0.0047^{* *}$ & $0.0018^{* *}$ \\
tests & $\mathrm{r}$ & 0.6660 & 0.7703 & 0.5471 \\
\hline
\end{tabular}

${ }^{*} P<0.05 ;{ }^{*} P<0.01 ;{ }^{* *} P<0.001 ; \mathrm{r}=$ Correlation coefficient, $\mathrm{P}=P$-value.

In ethological tests at 12 months, the highest vocalisation reaction was observed in group SB1, and the quietest heifers were group SB3 and SB4. At 19 months, there were no significant differences between the vocalisation response according to the season of the birth. This is probably related to the slower passing of labyrinth tests by SB1. These heifers had more difficulty solving individual issues; they were uncertain and mooed the most. It seems that season of the birth is a critical factor determining animals' ability to respond to environmental change. Increases in the productive capability of domestic animals can compromise thermal acclimation and plasticity, requiring greater investments in housing systems that reduce the variability of the thermal environment.

Some sires showed a higher level of activity and better ability to learn in the maze (Kovalcikova et al 1988; Broucek et al 2003; Arave et al 1992a). But our results obtained during observations in the labyrinth test did not confirm this hypothesis. During the research of the labyrinth behaviour, the influence of the Father factor was not proven either in the time of standing or in the time of its crossing. The problem probably lies in a suitable method of testing. It is also possible that the Holstein breed animals are not easy to 
evaluate because of their very docile temperament and discipline.

However, significant significance was recorded in the distribution of heifers by fathers in the $12^{\text {th }}$ month. Generally, the group ascended after F4 had the most vocalisation and group F1 the least in all tests. The father lineage influences a large part of the population, so its genetic qualities are effective as a stabilisation factor. The entire adaptability of the population through the fathers can be important.

\subsection{Consistency of labyrinth behaviour over time}

The partial goal of this study was to explore if dairy heifers are consistent over time in resolving situations. Repeatability between the parameters of labyrinth behaviour at the age of 12 months and 19 months was very high. Significant positive correlations were calculated in all three indicators. Similar findings were also mentioned by other authors (Kovalcikova and Kovalcik 1987; Bünger and Kaphengst 1987; Jensen et al 1999), who compared the behaviour in open-field tests in heifers and calves. According to Schuster et al (2017), the behavior is repeatable and depends on animal personality, genetic background and environment of rearing. It was suggested that shorter intervals between tests and presenting the same object in all tests will improve the repeatability of the test results (Meagher et al 2016). We agree that the shorter the period between observations, the higher the repeatability. Seven months was not in the present experiment for too long. But even so, the high stability of these behavioural parameters was confirmed.

Long-term consistency in responsiveness to labyrinth tests has not been studied so far in dairy heifers. Also, there is limited information on relationships between the responsiveness of dairy cattle to learning ability tests. We proposed that the reactivity of calves to labyrinth tests is mediated by traits related to standing, locomotion, exploration, and vocalisation. The personality traits changes in cattle around sexual maturation are probably owing to major physiological changes that are accelerated at this time (Schuster et al 2017; Müller and von Keyserlingk 2006; Meale et al 2017; Lecorps et al 2018; Neave et al 2020). Our findings suggest that learning traits of dairy heifers change over ontogeny but become more consistent after sexual maturity.

\section{Conclusions}

This study was conducted to determine whether factors of the rearing, the season of the birth, and father lineage affect dairy heifers' behaviour from the 360th to the 570th day.

Heifers reared in individual housing (CR) appear the least adaptable at the labyrinth. Heifers raised by foster cows (US) showed the best orientation in the labyrinth facility and were the most adaptable. Heifers SB3 across the labyrinth the fastest; the slowest were heifers SB1. We found the longterm consistency of behavioural responses to the labyrinth.
The effect of the fathers' genotype was manifested only in the number of vocalisations during the labyrinth tests. The results indicate that the method used to rear heifers and the season of birth may significantly impact their later behaviour in puberty and first pregnancy.

\section{Conflict of Interest}

The authors declare that they have no conflict of interest.

\section{Funding}

This article was written based on data projects APVV-18-0121 of the SRDA, Slovakia, and Sustainable Smart Farming Systems 313011W112, supported by the Operational Programme Integrated Infrastructure and the European Regional Development Fund.

\section{References}

Albright JL, Arave CW (1997) The Behaviour of Cattle. CAB International.

Anderson JF, Bates DW (1984) Clinical Cold Stress in Calves: Identification, Environmental Considerations, Treatment and Prevention. The Bovine Practitioners 19:22-25.

Angrecka S, Herbut P (2015) Conditions for cold stress development in dairy cattle kept in free stall barn during severe frosts. Czech J Animal Science 60:81-87.

Arave CW, Lamb RC, Arambel MJ, Purcell D, Walters JL (1992a) Behaviour and maze learning ability of dairy calves as influenced by housing, sex and sire. Applied Animal Behaviour Science 33:149-163.

Arave CW, Albright JL, Armstrong DV, Foster WW, Larson LL (1992b) Effects of isolation of calves on growth, behavior, and first lactation milk yield of Holstein cows. Journal of Dairy Science 75:3408-3415.

Barth K (2020) Effects of suckling on milk yield and milk composition of dairy cows in cow-calf contact systems. Journal of Dairy Research 87(S1):133-137.

Beaver A, Meagher RK, von Keyserlingk MAG, Weary DM (2019) A systematic review of the effects of early separation on dairy cow and calf health. Journal of Dairy Science 102:5784-5810.

Bell DJ, Robertson J, Macrae AI, Jennings A, Mason CS, Haskell MJ (2021) The Effect of the Climatic Housing Environment on the Growth of Dairy-Bred Calves in the First Month of Life on a Scottish Farm. Animals 11:2516.

Bilik K, Niwinska B, Lopusanszka-Rusek M, Fijal J (2013) Optimisation of calf rearing according to organic principles. Annals of Animal Science 13:341-355.

Boissy A, Bouissou MF (1995) Assessment of individual differences in behavioural reactions of heifers exposed to various fear-eliciting situations. Applied Animal Behaviour Science 46:17-31.

Bouissou MF, Boissy A, Le Neindre P, Veissier I (2001) The social behaviour of cattle. In: Keeling LJ, Gonyou HW (eds) Social Behaviour in Farm Animals. CAB International, Wallingford, UK, pp 113-145.

Braastad BO (1998) Effects of prenatal stress on behaviour of offspring of laboratory and farmed mammals. Applied Animal Behaviour Science 61:159180.

Broom DM, Fraser AF (2007) Domestic Animal Behaviour and Welfare. CAB International.

Broucek J, Kisac P, Uhrincat M (2003) The effect of sire line on learning and locomotor behaviour of heifers. Czech Journal of Animal Science 48:387-394.

Broucek J, Uhrincat M, Sandor A, Arave CW, Waiblinger S, Hanus A, Kisac P (2002) Einfluss eines niedrigen Magnetfeldes auf Kälber während der pränatalen Entwicklung. Tierärztliche Umschau 57:241-248.

Broucek J, Uhrincat M, Kisac P, Hanus A (2021) Effect of different rearing condition on early age in the maze, open-field, and aversive behaviours in the dairy cow during the first lactation. Journal of Animal Behaviour and Biometeorology 9:2117. 
Budzynska M, Weary DM (2008) Weaning distress in dairy calves: effects of alternative weaning procedures. Applied Animal Behaviour Science 112:3339.

Burman OHP, Parker RMA, Paul ES, Mendl M (2008) Sensitivity to reward loss as an indicator of animal emotion and welfare. Biology Letters 4:330-333.

Buttler L, Russ D, Wright C (2006) Cold Stress and Newborn Calves. Extension Extra. Paper 73, South Dakota State University.

Bünger U, Kaphengst $P$ (1987) Zum Verhalten von Tränkkälbern in einer fremdartigen Umwelt. Monatshefte für Veterinärmedizin 42:378-383.

Carstens GE (1994) Cold thermoregulation in the newborn calf. Veterinary Clinics of North America: Food Animal Practice 10:69-106.

Collier RJ, Dahl GE, Van Baale MJ (2006) Major advances associated with environmental effects on dairy cattle. Journal of Dairy Science 89:1244-1253.

Coloma-García W, Mehaba N, Llonch P, Caja G, Such X, Salama AAK (2020) Prenatal heat stress effects on gestation and postnatal behavior in kid goats. PLoS One 15:e0220221.

Costa JHC, Daros RR, von Keyserlingk MAG Weary DM (2014) Complex social housing reduces food neophobia in dairy calves. Journal of Dairy Science 97:7804-7810.

Costa JHC, Meagher RK, von Keyserlingk MAG, Weary DM (2015) Early pair housing increases solid feed intake and weight gains in dairy calves. Journal of Dairy Science 98:6381-6386.

Costa JHC, von Keyserlingk MAG, Weary DM (2016) Effects of group housing of dairy calves on behavior, cognition, performance, and health. Journal of Dairy Science 99:2453-2467.

Dahl GE, Tao S, Laporta J (2020) Heat Stress Impacts Immune Status in Cows Across the Life Cycle. Frontiers in Veterinary Science 7:116. DOI: 10.3389/fvets. 2020.00116

de Oliviera D, Barth K, Haskell MJ, Hillmann E, Jensen MB, Johnsen JF, Mejdell C, Weiblinger A, Ferneborg S (2020) Methodology for experimental and observational animal studies in cow-calf contact systems. Journal of Dairy Research 87:115-121

de Passillé AM, Marnet PG, Lapierre H, Rushen J (2008) Effects of twice-daily nursing on milk ejection and milk yield during nursing and milking in dairy cows. Journal of Dairy Science 91:1416-1422.

de Paula Vieira A, de Passillé AM, Weary DM (2012) Effects of the early social environment on behavioral responses of dairy calves to novel events. Journal of Dairy Science 95:5149-5155.

European Commission (2007) Council Regulation (EC) No 834/2007 of 28 June 2007 on organic production and labelling of organic products and repealing Regulation (EEC) No 2092/91.

Flower FC, Weary DM (2001) Effects of early separation on the dairy cow and calf: 2 . separation at 1 day and 2 weeks after birth. Applied Animal Behaviour Science 70:275-284.

Flower FC, Weary DM (2003) The effects of early separation on the dairy cow and calf. Animal Welfare 12:339-348.

Foris B, Zebunke M, Langbein J, Melzer N (2018) Evaluating the temporal and situational consistency of personality traits in adult dairy cattle. PLoS One 13:e0204619. DOI.org/10.1371/journal.pone.0204619

Fröberg S, Gratte E, Svennersten-Sjaunja K, Olsson I, Berg C, Orihuela A Galina CS, Garcia B, Lidfors L (2008) Effect of suckling ('restricted suckling') on dairy cows' udder health and milk let-down and their calves' weight gain feed intake and behaviour. Applied Animal Behaviour Science 113:1-14.

Gaillard C, Meagher RK, von Keyserlingk MAG, Weary DM (2014) Social housing improves dairy calves' performance in two cognitive tests. Plos One 9:e90205.

Gibbons JM, Lawrence AB, Haskell MJ (2010) Measuring sociability in dairy cows. Applied Animal Behaviour Science 122:84-91.

Gordon N (1997) Nutrition and cognitive function. Brain Development 19:165-170.

Graunke KL, Nürnberg G, Repsilber D, Puppe B, Langbein J (2013) Describing Temperament in an Ungulate: A Multidimensional Approach. PLoS One

\section{8:e74579. DOI:10.1371/journal.pone.0074579.}

Gräbner M, Kanitz E, Otten W (2009) Pränataler Stress bei Nutztieren: Eine Übersicht. Berliner und Münchener tierärztliche Wochenschrift 122:73-81.

Green AC, Johnston IN, Clark CEF (2018) Invited review: The evolution of cattle bioacoustics and application for advanced dairy systems. Animal 12:1250-1259.

Han CS, Dingemanse NJ (2015) Effect of diet on the structure of animal personality. Frontiers in Zoology 12:S5.

Hedlund L, Løvlie H (2015) Personality and production: Nervous cows produce less milk. Journal of Dairy Science 98:5819-5828.

Hempel S, Menz Ch, Pinto S, Galan E, Janke D, Estellés F, Müschner-Siemens T, Wang X, Heinicke J, Zhang G, Amon B, del Prado A, Amon T (2019) Heat stress risk in European dairy cattle husbandry under different climate change scenarios - uncertainties and potential impacts. Earth System Dynamics 10:859-884.

Herbut P, Angrecka S, Godyń D, Hoffmann G (2019) The physiological and productivity effects of heat stress in cattle - a review. Annals of Animal Science 19:579-594.

Herbut P, Angrecka S, Walczak J (2018) Environmental parameters to assessing of heat stress in dairy cattle - a review. International Journal of Biometeorology 62:2089-2097.

Herbut P, Hoffmann G, Angrecka S, Godyń D, Corrêa Vieira FM, Adamczyk K, Kupczyński R (2021) The effects of heat stress on the behaviour of dairy cows. Annals of Animal Science 21:385-402.

Hopster H, van der Werf JTN, Blokhuis HJ (1998) Side preference of dairy cows in the milking parlour and its effects on behaviour and heart rate during milking. Applied Animal Behaviour Science 55:213-229.

Horvath K, Fernandez M, Miller-Cushon EK (2017) The effect of feeding enrichment in the milk-feeding stage on the cognition of dairy calves in a $T$ maze. Applied Animal Behaviour Science 187:8-14.

Horvath K, Miller-Cushon EK (2018) Characterising social behavior, activity, and associations between cognition and behavior upon social grouping of weaned dairy calves. Journal of Dairy Science 101:7287-7296.

Jensen MB, Larsen LE (2014) Effects of level of social contact on dairy calf behavior and health. Journal of Dairy Science 97:5035-5044.

Jensen MB (1999) Effects of confinement on rebounds of locomotor behaviour of calves and heifers, and the spatial preferences of calves. Applied Animal Behaviour Science 62:43-56.

Johnsen JF, Passillé de AM, Mejdell CM, Boe KE, Grondahl AM, Beaver A, Rushen J, Weary DM (2015) The effect of nursing on the cow-calf bond. Applied Animal Behaviour Science 163:50-57.

Johnsen JF, Zipp KA, Kalber T, Passillé de AM, Knierim U, Barth K, Mejdell CM (2016) Is rearing calves with the dam a feasible option for dairy farms? Applied Animal Behaviour Science 181:1-11.

Johnsen JF, Holmoy IH, Nodtvedt A, Mejdell CM (2021) A survey of pre-weaning calf management in Norwegian dairy herds. Acta Veterinaria Scandinavica 63:20.

Kent JP (2020) The cow-calf relationship: from maternal responsiveness to the maternal bond and the possibilities for fostering. Journal of Dairy Research 87(S1):101-107.

Kilgour R (1981) Use of the Hebb-Williams closed-field test to study the learning ability of Jersey cows. Animal Behaviour 29:850-860.

Kilgour R (1987) Learning and the Training of Farm Animals. Veterinary Clinics of North America: Food Animal Practice, Farm Animal Behavior 3:269-284.

Kälber T, Barth K (2014) Practical implications of suckling systems for dairy calves in organic production systems - a review. Landbauforschung-Applied Agricultural and Forestry Research 64:45-58.

Kovalcikova M, Kovalcik K (1987) Differences in the responses of heifers in the course of behavioural tests during ontogenesis. Zivocisna Vyroba 32:8794.

Kovalcikova M, Kovalcik K, Broucek J (1988) The effects of the bull on the reactions and adaptability of the daughters in behavioural tests. Zivocisna 
Vyroba 33:201-209.

Köllmann K, Zhang Y, Wente N, Lücken A, Leimbach S, Krömker V (2021) Effects of Suckling on the Udder Health of Foster Cows. Ruminants 1:100117.

Krachun C, Rushen J, de Passillé AM (2010) Play behaviour in dairy calves is reduced by weaning and by a low energy intake. Applied Animal Behaviour Science 122:71-76.

Krohn CC (2001) Effects of different suckling systems on milk production, udder health, reproduction, calf growth and some behavioural aspects in high producing dairy cows-a review. Applied Animal Behaviour Science 72:271-280.

Lapin M, Fasko P, Melo M, Stastny P, Tomlain J (2002) Climate areas. In: Atlas of Slovakia country. Ministry of Environment of the Slovak Republic and Slovak Environment Agency, Bratislava, pp 77- 94.

Laporta J, Fabris TF, Skibiel AL, Powell JL, Hayen MJ, Horvath K, Miller-Cushon EK, Dahl GE (2017) In utero exposure to heat stress during late gestation has prolonged effects on the activity patterns and growth of dairy calves. Journal of Dairy Science 100:2976-2984

Latham NR, Mason GJ (2008) Maternal deprivation and the development of stereotypic behaviour. Applied Animal Behaviour Science 110:84-108.

Lauber MCY, Hemsworth PH, Barnett JL (2006) The effects of age and experience on behavioural development in dairy calves. Applied Animal Behaviour Science 99:41-52.

Lecorps B, Weary DM, von Keyserlingk MAG (2018) Pessimism and fearfulness in dairy calves. Scientific Reports 8:1421. DOI:10.1038/s41598017-17214-3

Le Neindre P (1989) Influence of rearing conditions and breed on social behaviour and activity of cattle in novel environments. Applied Animal Behaviour Science 23:129-140.

Loberg J, Lidfors L (2001) Effect of stage of lactation and breed on dairy cows' acceptance of foster calves. Applied Animal Behaviour Science 74:97-108.

Loberg JM, Hernandez CE, Thierfelder T, Jensen MB, Berg Ch, Lidfors L (2008) Weaning and separation in two steps - A way to decrease stress in dairy calves suckled by foster cows. Applied Animal Behaviour Science 111:222234.

Manteuffel G, Puppe B, Schön PC (2004) Vocalisation of farm animals as a measure of welfare. Applied Animal Behaviour Science 88:163-182.

Margerison JK, Phillips CJC, Preston TR, The effect of restricted suckling and nutrition on lactation, reproduction and calf development. Proceedings British Society of Animal Science 37:62-65.

Meagher RK, Daros RR, Costa JHC, von Keyserlingk MAG, Hötzel MJ, Weary DM (2015) Effects of Degree and Timing of Social Housing on Reversa Learning and Response to Novel Objects in Dairy Calves. PLoS ONE 10:e0132828. doi: 10.1371/journal.pone.0132828

Meagher RK, von Keyserlingk MAG, Atkinson D, Weary DM (2016) Inconsistency in dairy calves' responses to tests of fearfulness. Applied Animal Behaviour Science 185:15-22.

Meagher RK, Beaver A, Weary DM, von Keyserlingk MAG (2019) A systematic review of the effects of prolonged cow-calf contact on behavior, welfare, and productivity. Journal of Dairy Science 102:5765-5783.

Meale SJ, Chaucheyras-Durand F, Berends H, Guan LL, Steele MA (2017) From pre- to postweaning: Transformation of the young calf's gastrointestinal tract. Journal of Dairy Science 100:5984-5995.

Meen GH, Schellekens MA, Slegers MHM, Leenders NLG, Van Erp-Van de Kooij E, Noldus LP (2015) Sound analysis in dairy cattle vocalisation as a potential welfare monitor. Computers and Electronics in Agriculture 118:111-115.

Melo M, Lapin M, Damborska I (2009) Methods for the design of climate change scenario in Slovakia for the 21st century. Bulletin of Geography. Physical Geography Series 1:77-90.

Miguel-Pacheco G, Vaughan A, de Passillé A, Rushen J (2015) Relationship between locomotor play of dairy calves and their weight gains and energy intakes around weaning. Animal 9:1038-1044.
Müller R, Schrader L (2005a) Individual Consistency of Dairy Cows' Activity in Their Home Pen. Journal of Dairy Science 88:171-175.

Müller R, Schrader L (2005b) Behavioural consistency during social separation and personality in dairy cows. Behaviour 142:1289-1306.

Müller R, von Keyserlingk MAG (2006) Consistency of flight speed and its correlation to productivity and to personality in Bos taurus beef cattle. Applied Animal Behaviour Science 99:193-204.

Neave HW, Costa JHC, Weary DM, von Keyserlingk MAG (2020) Long-term consistency of personality traits of cattle. Royal Society Open Science 7:191849.

Nonnecke BJ, Foote MR, Miller BL, Fowler M, Johnson TE, Horst RL (2009) Effects of chronic environmental cold on growth, health, and select metabolic and immunologic responses of preruminant calves. Journal of Dairy Science 92:6134-6143.

Novak P, Vokralova J, Tittl K, Mala G, Illek J (2010) Selected aspects of welfare and prevention of disease in ruminants. Veterinarstvi 60:25-27.

Purcell D Arave CW (1991) Isolation vs. group rearing in monozygous twin heifer calves. Applied Animal Behaviour Science 31:147-156.

Rashamol VP, Sejian V, Bagath M, Krishnan G, Archana PR, Bhatta R (2018) Physiological adaptability of livestock to heat stress: an updated review. Journal of Animal Behaviour and Biometeorology 6:62-71.

Reenen van CG, van der Werf JTN, O'Connell NE, Heutinck LFM, Spoolder HAM, Jones RB, Koolhaas JM, Blokhuis HJ, O'Connell NE (2013) Behavioura and physiological responses of heifer calves to acute stressors: Long-term consistency and relationship with adult reactivity to milking. Applied Animal Behaviour Science 147:55-68.

Renaudeau D, Collin A, Yahav S, de Basilio V, Gourdine JL, Collier RJ (2012) Adaptation to hot climate and strategies to alleviate heat stress in livestock production. Animal 6:707-728.

Roland L, Drillich M, Klein-Jöbstl D, Iwersen M (2016) Influence of climatic conditions on the development, performance, and health of calves. Journal of Dairy Science 99:2438-2452.

Roman L, Morales Pineyrua JT, Banchero G, La Manna A (2021) Access to shade during the dry period improves the performance of multiparous Holstein cows. Animal Production Science 61:1706-1714.

Romeyer A, Bouissou MF (1992) Assessment of fear reactions in domestic sheep, and influence of breed and rearing conditions. Applied Animal Behaviour Science 34:93-119.

Roth BA, Barth K, Gygax L, Hillmann E (2009) Influence of artificial vs. motherbonded rearing on sucking behaviour, health and weight gain in calves. Applied Animal Behaviour Science 119:143-150

Rushen J, de Passillé AM (1998) Behaviour, welfare and productivity of dairy cattle. Canadian Journal of Animal Science 78(Suppl):3-21

Rushen J, de Passillé AMB, von Keyserlingk MAG, Weary DM (2008) The welfare of cattle. Springer, Dordrecht, Netherlands

Schrader L (2002) Consistency of individual behavioural characteristics of dairy cows in their home pen. Applied Animal Behaviour Science 77:255-266.

Schuster AC, Carl T, Foerster K (2017) Repeatability and consistency of individual behaviour in juvenile and adult Eurasian harvest mice. The Science of Nature 104:10. DOI:10.1007/s00114-017-1430-3

Shetty PS (1999) Adaptation to low energy intakes: the responses and limits to low intakes in infants, children and adults. European Journal of Clinical Nutrition 53(Suppl 1):S14-S33.

Siebert K, Langbein J, Schön PC, Tuchscherer A, Puppe B (2011) Degree of social isolation affects behavioural and vocal response patterns in dwarf goats (Capra hircus). Applied Animal Behaviour Science 131:53-62.

Slavik P, Illek J, Brix M, Musilova L, Rajmon R, Klabanova P, Jilek F (2009) Health Status of Beef Cows and their Calves in the Czech Republic. Acta Veterinaria Brno 78:47-56.

Steele M (2019) Performance and Behavioural Effects of Separating Dairy Cows and Their Calves at Birth. Veterinary Evidence 4:24.

Stehulova I, Lidfors L, Spinka M (2008) Response of dairy cows and calves to 
early separation: effect of calf age and visual and auditory contact after separation. Applied Animal Behaviour Science 110:144-165.

Stehulova I, Spinka M, Sarova R, Machova L, Knez R, Firla P (2013) Maternal behaviour in beef cows is individually consistent and sensitive to cow body condition, calf sex and weight. Applied Animal Behaviour Science 144:89-97.

Tao S, Bubolz JW, do Amaral BC, Thompson IM, Hayen MJ, Johnson SE, Dahl GE (2011) Effect of heat stress during the dry period on mammary gland development. Journal of Dairy Science 94:5976-5986.

Tao S, Monteiro APA, Thompson IM, Hayen MJ, Dahl GE (2012) Effect of lategestation maternal heat stress on growth and immune function of dairy calves. Journal of Dairy Science 95:7128-7136.

Tao S, Dahl GE (2013) Heat stress effects during late gestation on dry cows and their calves. Journal of Dairy Science 96:4079-4093.

Uhrincat M, Broucek J, Hanus A, Kisac P (2021) Effect of Raising Dairy Heifers on Their Performance and Reproduction after 12 Months. Agriculture 11:973.

Valnickova B, Stehulova I, Sarova R, Spinka M (2015) The effect of age at separation from the dam and presence of social companions on play behaviour and weight gain in dairy calves. Journal of Dairy Science 98:55455556.

Veissier I, Le Neindre P (1992) Reactivity of Aubrac heifers exposed to a novel environment alone or in groups of four. Applied Animal Behaviour Science 33:11-15.

Veissier I (1993) Observational learning in cattle. Applied Animal Behaviour Science 35:235-243.

Ventura G, Lorenzi V, Mazza F, Clemente GA, lacomino C, Bertocchi L, Fusi F (2021) Best Farming Practices for the Welfare of Dairy Cows, Heifers and Calves. Animals 11:2645. von Keyserlingk MAG, Weary DM (2007) Maternal behaviour in cattle: A review. Hormones and Behavior 52:106-113.

von Keyserlingk MAG, Rushen J, de Passillé AM, Weary DM (2009) The welfare of dairy cattle-key concepts and the role of science. Journal of Dairy Science 92:4101-4111.

Wagenaar JPTM, Langhout J (2007) Practical implications of increasing 'natural living' through suckling systems in organic dairy calf rearing. NJAS Wageningen Journal of Life Sciences 54:375-386.

Wagner K, Seitner D, Barth K, Palme R, Futschik A, Waiblinger S (2012) Integration into the dairy cow herd: Long-term effects of mother contact during the first twelve weeks of life. Applied Animal Behaviour Science 141:117-129.

Wagner K, Barth K, Hillmann E, Palme R, Futschik A, Waiblinger S (2013) Mother rearing of dairy calves: reactions to isolation and to confrontation with an unfamiliar conspecific in a new environment. Applied Animal Behaviour Science 147:43-54.

Wagner K, Seitner D, Barth K, Palme R, Futschik A, Waiblinger S (2015) Effects of mother versus artificial rearing during the first 12 weeks of life on challenge responses of dairy cows. Applied Animal Behaviour Science 164:111.

Wechsler B, Lea SEG (2007) Adaptation by learning: Its significance for farm animal husbandry. Applied Animal Behaviour Science 108:197-214.

Winder CB, Bauman CA, Duffield TF, Barkema HW, Keefe GP, Dubuc J, Uehlinger F, Kelton DF (2018) Canadian National Dairy Study: Heifer calf management. Journal of Dairy Science 101:1-15.

Zhang C, Juniper DT, Meagher RK (2021) Effects of physical enrichment items and social housing on calves' growth, behaviour and response to novelty. Applied Animal Behaviour Science 237:105295. 